\title{
Ethnic Deviant Labels within a Terror-Panic Context: Excusing White Deviance
}

\author{
by Tina Patel, University of Salford
}

\begin{abstract}
This paper considers ethnically loaded deviant labels within a terror-panic context that is specifically embedded in a framework that refers to failed multiculturalism. It complements existing literature on the subject by discussing how the continued construction of negative labels with reference to 'brown bodies' limits the life chances and freedoms of this population group. The paper however argues that constructing brown bodies as deviant also allows for any actual deviant labels associated with white bodies within the same context to be excused or at least more readily excused in comparison to their brown bodied counterparts. This is possible because of the normality and central position of whiteness, which places its subjects in a relative position of power and authority. The paper argues that a panic-driven preoccupation with the brown body within the terror-panic context means that white bodies are often passed over for attention, even in instances where problematic behaviour is evident.
\end{abstract}

We are supposedly living in post-race times. This refers to a deconstructive approach to identity and social relations, in an attempt to move beyond traditional constructions of race. More recently, within the 'war on terror' context, post-race discussions have specifically been considered within debates about citizenship, community cohesion, multiculturalism and securitisation. This has produced a multiculturalism - national identity - terrorism narrative that makes reference to inclusiveness and legalistic measures for combating racism, and yet in reality results in the securitisation of racerelations and black and minority ethnic populations. The 'war on terror' has been articulated in ways which produce a new mode of racism and ethnic discrimination, for instance what is referred to as 'xeno-racism'. This allows discriminatory practices to continue in ever more intensified, state 'legitimated' and publicly accepted ways. For example, consider the regimes of racial spatialization and bodily control in stop and search practices under the Police and Criminal Evidence Act (1984) (1) and sections 44 and 45 of the Terrorism Act (2000) (2).

Using the case of the recent terror-panics, in particular its narrative around the 'Islamic terrorist', this paper looks at how constructions of deviance continue to draw on an already embedded racist discourse, which is delivered within rhetoric of anti-Muslim racism and white (3) superiority. It is argued that when certain constructions of deviance occur, there is at the same time a dissolving of the deviance perpetuated by others in the same context. Within the terror-panic context, this is an ethnically loaded process. The paper draws on the work of Goffman (1963) and Becker (1963), in order to develop understanding of how deviants not only exist in relation to those they are seen to threaten and those who have enough power to control them (Pfohl 2002), but also how their deviant status is often used to cover the deviance of desirable 'normals'. In recent times, and especially within the terror-panic context, this occurs by presenting particular black and minority ethnic groups, namely those of Middle Eastern appearance, or of South Asian or Arabic heritage and of the Muslim faith, or what I term in this paper: 'brown bodies', as criminal, i.e. the 'Islamic terrorist'. At the same time, other ethnic groups, largely those of European heritage and of a Christian faith, i.e. what I term in this paper: 'white bodies', are largely situated as un-problematic. This is because white bodies are able to draw on the centrality and normality of whiteness in order to detach labels of deviance. This occurs even when the latter is associated with behaviour and activity that is clearly deviant and discriminatory, i.e. the English Defence League (4) and the shooting of Jean Charles de Menezes (5). 
In these cases, deviant behaviour was largely viewed as relatively non-serious given that it was being compared to the (imagined) deviance of brown bodies. This led to the excusing of white deviance as an understandable response to some other ethnic threat. With its national identity and anti-immigration framing, this echoes discourses of whiteness and 'neo-colonial' fantasy (Burdsey 2011), and some may argue points to the wider processes of racialised governance (Patel and Tyrer 2011).

\section{Racialisation and Browning within the Terror-Panic Context}

The events that unfolded on 11th September 2001 in the US and later in the UK on 7th July 2005 (commonly known as 9/11 and 7/7), were without doubt distressing atrocities. They remain embedded in our memories and human history as some of the most significant events of our time. The tragedy of the events were broadcasted to us live - the emotional language and constant re-playing of distressing images adding to our upset, anxiety, fear, and panic. These events were real and touched each and every one of us in a personal way, connecting us all to what had happened. For instance we are able to recall where we were and what we were doing when we heard of the events - a memory imprint usually reserved for intimate life moments, i.e. the first time you fell in love, the death of a family member, the birth of your child. This allowed hatred for those considered responsible to fester (6). This was done by using racialisation processes underpinned with Islamophobia and antiMuslim racism. Ethnically loaded fear was sustained due to the steady flow of terrorism-related news that is fed to us on a regular basis. It is not surprising then, given the politics of fear and emotionally charged re-presentations of terrorism and national security, which have inaccurately presented Islam as a pre-disposing factor of terrorist behaviour, that wider public support has been given to state officials and those charged with security duties, to introduce new measures and heighten existing ones that promise to deliver protection. This has resulted in Islamophobic measures which see some ethnic groups being targeted and monitored, not for what they have done, or even what they believe, but rather for who they are imagined to be (Younge 2003, p. 117). These bodies are also presented as evidencing the death of multiculturalism (Gilroy 2006) - a view popularised by common use of terms such as 'homegrown terrorist' and 'the enemy within' to supposedly highlight the failings of brown bodies and other 'foreigners' to meet the assimilation expectations of mainstream British society. The result is an opportunity for the government and its allied state officials to claim that solidarity and diversity cannot co-exist (Gilroy 2006), and to use this 'realisation' to call for membership to a particular notion of national identity and British patriotism. However, the construction of Britishness, Gilroy (2005) argues, is a problematic one given that it is shaped by Britain's uneasy understanding of its own empire and postcolonial history - what Gilroy calls 'the neurotic development of postcolonial or post-imperial melancholia' - and its tendency to view Britishness through an 'airbrushed, nuanced and nostalgic filter' (2005, pp. 434-437).

A terror-panic context which is framed by such debates about national identity, citizenship, multiculturalism and religious conflict, has resulted in one black and minority ethnic category in particular being selectively presented as a unique type of dangerous ethnic other (Razack 2008). This paper refers to this category as 'brown bodies'. This is a label that makes reference to the specific positioning of this group within the spectrum of perceived ethnic deviance, as well as the racialisation processes that are used in constructing this group as a particular type of deviant category. In using cultural and non-essentialist notions of difference to mark out brown bodies, it is useful to draw on the work of Meer and Modood (2010) who point out that contemporary anti-Muslim racism can be linked to the racial hierarchies of European empires, as well as to Christian Islamophobia and the Crusades of earlier centuries (Gottschalk and Greenberg 2008, cited in Meer and Modood 2010, p. 117). This results in 'browning' having a religious and culturally racist element to it, which has partially been developed using phenotypical (biological) components: this has turned 'an ethno-religious group into a race' (Meer and Modood 2010, p. 117). In addition, 'browning' is also a strategy of imposed identification (Burman 2010; Semati 2010), which 'seeks to sort the ally from the enemy, the model minority I informant/ 'good Muslim' from the suspect / extremist / 'bad Muslim'...[this] cast[s] the net of suspicion 
widely in order to justify new policy frameworks' (Burman 2010, p. 239). Lugo-Lugo and BloodsworthLugo (2010) note that in this sense 'browning' is not a positive process - something that has often been argued by making reference to celebrations of multiculturalism. Rather, within the terror-panic climate, the growing allocation of 'brown labels' has created fear and insecurity - what Lugo-Lugo and Bloodsworth-Lugo call a 'browning of terror' (2010, p. 240). Browning is about articulating, in a racialised way, the perceived security threats of the white national imaginary. Browning is so powerful that it can sometimes lead to the imagining of items associated with ethnic deviant behaviour (terrorism). For instance, consider the case of Jean Charles de Menezes, where eyewitness accounts following the shooting of Menezes referred to 'a man of Asian appearance' (Menezes) who 'appeared to have a bomb belt with wires coming out' (Stockwell passengers quoted in BBC News 22nd July 2005). One eyewitness reported seeing 'an Asian man run onto the train wearing a thick padded coat, which he thought unusual for the time of year' (Witness YH, quoted in Independent Police Complaints Commission 2007, p. 68). Another witness too recalled how 'his attention was drawn toward an Asian man who ran into the carriage' (Witness YG quoted in Independent Police Complaints Commission 2007, p. 68). Three key ethnic symbols are significant here when taken within the terror-panic context: the heavy padded jacket; the bomb belt and wires; and, the 'Asian man' - all of which were later revealed as having been imagined as there was no heavy padded winter coat, but a lightweight denim jacket; there was no bomb belt or wires, and Menezes was not Asian. What occurred though in this scenario was Menezes and the items on his person, were being 'visually resignified' (Pugliese 2006) and re-presented as deviant, in particular within imagined images of a terrorist, at all stages of the shooting: before (by the surveillance team), during (by the eyewitnesses), and after (by the Metropolitan Police Force's doctored images of Menezes). Brown bodies are presented as deviant, or at the very least as 'illegal bodies' posing a problem for 'community cohesion'. Unsurprisingly, there is a general reluctance to view the Islamophobic or anti-Muslim sentiments of browning, which go on to inform security measures, as a form of victimisation or racism (Meer and Modood 2010). This gives support for increased security measures, meaning that the 'inconveniences' these are seen to cause for brown bodies are rationalised within the white imagination and considered to outweigh the promised benefits of national security and safety from terrorism - after all, the rationale goes that if one is innocent, they will be exonerated (Bahdi 2003).

In reality though, there is very little evidence to support the claim that these security promises can be fulfilled (Ball and Webster 2003). Rather what we have is a situation where brown bodies, some of whom have been reported to officials by members of the public, have experienced 'routine and focused attention to personal details for the purposes of influence, management, care, and control' (Lyon 2006, p. 403). For example, the UK has seen an unprecedented increase in the stopping and searching of brown bodies under sections 44 and 45 of the Terrorism Act (2000). It is a practice that is clearly discriminatory, and unapologetically so: 'Terrorists are likely to be linked to sectors of the community that, because of their racial, ethnic or geographical origins, are readily identifiable' (Lord Hope to the House of Commons Home Affairs Committee Sixth Report of Session 2004-2005: Terrorism and Community Relations, cited in Moeckli 2007, p. 663). The discriminatory and problematic use of stop and search under sections 44 and 45 was noted in July 2010 when the Home Secretary, following a ruling by the European Court of Human Rights, stated that the police would only now be able to carry out stop and searches if they had 'reasonable suspicion of terrorist activity' (Guardian 8th July 2010). The new guidelines reflected concerns about the broad interpretation of sections 44 and 45 , the possibilities of anti-Muslim racist victimisation, and the threat to civil liberties (Patel and Tyrer 2011). However, 'browning' within the terror-panic context continues to powerfully 'relegitimise state racism' (Bhattacharyya 2008, p. 75), as well as those views common in lay society. It does this by highlighting notions of 'brown difference' that are cultural, non-essential, and unlike past violence against other black and minority ethnic groups. In doing so, there is an attempt to move away from accusations of racism. Yet in reality, 'browning' remains discriminatory as it continues to link a particular black and minority ethnic body with a particular set of negative social meanings (Bhattacharyya 2008, p. 58). 
Under various guises, brown bodies have a long history of discriminatory treatment by the state and its agents. This is rooted in 'Orientalist' ideas of the 'West', which have been produced for many centuries (Harewood 2010; Said 1978; Semati 2010). It is important to recognise therefore that Islamophobia and anti-Muslim racism was common before the recent terror-panic context (Allen 2010). However, it is argued that the events of 9/11 routinely intensified and normalised browning processes. This led to the problematising of those marked out as deviant or suspicious, which further went on to provide 'a convenient opportunity' for the 'increased surveillance' and control of brown bodies (Haggerty and Gazso 2005, p. 169). This included heightened policing through disproportionate and increased levels of stop and search; the refusal of admission into certain areas; the inclusion of personal data on 'suspect' data mining reports; and, being subjected to increased recording or observation mechanisms (CCTV cameras). These all demonstrate and further allow for a centralized, state-driven governance of particular bodies and spaces in a way that is publicly supported by majority society (Lyon 2007). Clearly a racialised profiling process is taking place where 'whole categories of phenotypically similar individuals are rendered pre-criminal and morally suspect' (Covington 1995, p. 547).

An atmosphere of fear and a 'permission to hate' is created (Perry 2001, p. 179), where 'moral panics' about the brown body fester (Young 1971; Cohen 1972; Hall et al. 1978). Demonization of the brown folk devil within this terror-panic is fed by the view that these newer forms of terrorism outweigh any dangers of the older terror threats, not least because of claims about the indiscriminate nature of the first: 'Al-Qaeda have re-written the manual of attack..... [the Irish Republican Army] was somewhat easier to manage.....They didn't want to commit suicide. The aim of the game now is mass murder' (Det. Chief Supt. Tony Porter, Head of Counter Terrorism Unit, Greater Manchester Police, cited in Manchester Evening News 8th April 2008). The argument being that the olderterrorist (Irish Republican Army) targets were more predictably focused and often gave advance warnings before bombs were detonated. Added to this is the argument that even the Irish Republican Army had some sense of morality and wanted to escape alive afterwards, and so wouldn't consider indiscriminate attacks on soft targets or taking part in suicide missions. In comparison, 'new terrorism', by which we read 'Islamic terrorism', is considered to be 'driven by hatred, fanaticism and extremism', with there being 'no possibility of negotiation, compromise or appeasement' (Jackson 2006, p. 11-12). Here lies the 'Islamic terrorism' discourse, which although 'laden with its own set of unacknowledged assumptions and embedded cultural narratives', nevertheless remains politically and culturally powerful (Jackson 2006, p. 2).

This is a significant feature of how deviant labels relating to ethnicity and crime are currently addressed. Here it is observed that we are in the UK, working within a post-race and post-Macpherson (7) era, and that the equivalent is occurring elsewhere, e.g. Australia, Canada, France, Germany and the USA. Yet, despite this there exists the continued problematic construction of crimes as being based on ethnic markers. Although ideas about ethnic markers of crime are now largely based on cultural racism, as opposed to the biological racism used in the past, the outcome is still the same. Older and soundly disputed ideas of 'black criminality' are not only being re-worked, but are done so in ways that are more palatable, directly taking brown bodies as objects in need of state intervention (8). It does this while either claiming not to be racist in the biological sense of the term, or by suggesting that any ensuing discrimination is somehow legitimated (Patel and Tyrer 2011). This allows a form of social sorting to occur, which is being informed by cultural variables, such as religion, nationality, etc, alongside 'other' markers of suspicion - we are never fully certain of the exact content of the latter, but reference to the broad category of 'suspicious behaviour' is often marked as significant. These combine to inform perceptions of deviance and the use of security measures. The problem here though is that, although this suggests a move away from the biological racism of past eras, it nevertheless is a form of cultural racism, whose racialisation processes rely heavily on Islamophobic sentiments or anti-Muslim racism, themselves embedded within in a problematic notion of a British national identity. 


\section{Controlling Dangerous Brown Bodies}

There is ample evidence and illustration of the negative presentation of black and minority ethnic groups in the mass media - see for instance the work of Malik (2002); Sommers et al. (2006); Entman (1990); and most notably that of Hall et al. (1978). Recent work has focused on the mass media's mis-representation of brown bodies, and in particular how this has served to sustain Islamophobic sentiments and anti-Muslim racism, so much so that it is now a common feature of contemporary society - see for instance the work of Ahmad (2006); Khiabany and Williamson (2008); Moore et al. (2008); Poole (2002); Poole and Richardson (2006); Richardson (2004); and Saeed (2007). The presentation of brown bodies 'through images of danger, violence and anger' (Alexander 2005, $\mathrm{p}$. 200), are further embodied and re-imagined within the context of 'the enemy within', itself linked to debates about 'community cohesion' (Alexander 2005; Dwyer et al. 2008), and steeped in 'domestic repression, carried out in the name of national security' (Mathur 2006, p. 34). This process of stigmatising has occurred alongside the government's 'community cohesion' agenda, both as they resonate with older racist arguments about assimilation (Worley 2005) and as they intersect with the trajectories of wars against immigrants, asylum seekers and terrorism (Sivanandan 2006). This articulates new forms of racialised governance that are concerned with the controlling of ethnic bodies and other issues of spatiality (Patel and Tyrer 2011). The presentation is clearly racist, as it reinforces the notion that whiteness is linked to true Britishness (or Americanness, Europeanness, etc.), and is designed to intimidate and justify greater control and surveillance of brown 'suspect' bodies. The management and control of these groups, under the rouge of anti-terror methods, therefore has a wider remit. They are seen as part of a broader citizenship and social ordering agenda (Patel and Tyrer 2011). This is evidenced by the 'immigration sweeps' witnessed immediately following $9 / 11$ in the USA, as Mathur (2006) discusses:

.....the FBI began randomly interviewing thousands of men with Muslim names, creating further panic. Working on the assumption that any Muslim might have connections to, or information about, the attacks on the World Trade Center and the Pentagon, law enforcement officials began picking up South Asian and Middle Eastern men off the streets, from their homes and from their workplaces. Arrests were made on the basis of tips, reports of "suspicious activity", which apparently consisted of having a South Asian or Middle Eastern appearance. These reports came largely from neighbours, disgruntled colleagues, employee, ex-girlfriends, or landlords (p. 34).

The state and its ideological apparatus therefore plays a key role in demanding that we de-contextualise discussions by focusing, not on specific spatial and structural contexts from which the social problems sustaining this discourse emerged, but rather on the culturally essentialised, pathological nature of black and minority ethnic subjects (Patel and Tyrer 2011). Of particular attention is their supposed inability to integrate or prove membership to British society - see for instance accusations of identity conflict and self-segregation of British Asian Muslims (Kundnani 2007) and consequential calls for restrictions on both future numbers of others like them, and their right to establish separate and distinct cultural groupings living in sub-isolation from mainstream British culture (McGhee 2005). Within the terror-panic climate, the results are situations where there is a clear link between one's ethnic background and the views held about the propensity to commit certain crimes (terrorism), for example as evidenced in the recent calls made in the UK's higher education system to monitor international students as well as placing new restrictions on their numbers, and as witnessed elsewhere in Europe, for instance as we saw with the German authorities' use of Rasterfahndung (9) (De Schutter and Ringelheim 2008, p. 359).

Such ethnically marked practices remain despite their discriminatory nature, heavy-handedness and ineffective outcomes. For example, following 9/11, the US Terrorism Task Forces detained at least 1,200 people - most of whom were of Arab, South Asian and Muslim heritage, who had been targeted following data-mining exercises and from some of the 96,000 'tips' from members of the public in the 
first week after the $9 / 11$ attacks. Although not one single person had been charged in connection with the attacks or any other terrorist activity, many were later deported (Murray 2010, p. 12). Brown bodies themselves have reported feeling as if they were being viewed as a 'suspect community' (Spalek, El Awa and McDonald 2009, p. 17), of which there were very real consequences in other parts of their lives, i.e. family breakdown, job loss and ostracisation from the wider community. This further hinders any interest to participate in wider state or police-community engagement initiatives (Spalek et al. 2009). Kundnani (2009) illustrates this when discussing how respondents in his study talked about participation in the UK's Preventing Violent Extremism Programme (Prevent), which, with a budget of $f 140$ million in 2008/9, offered funding to voluntary sector organisations to undertake projects which sought to develop community cohesion strategies and a community-led approach to tackling violent extremism (pp. 6-8). One respondent stated that they 'decided not to get involved in Prevent because it reinforces the association with Islam and terror, and it implies acceptance of responsibility' (respondent in interview 12, cited in Kundnani 2009, p. 27). Another respondent who had chosen to be involved in Prevent had stated: 'Working on Prevent has been draining mentally.....We can smell the stench of Islamophobia' (respondent in interview 9, cited in Kundnani 2009, p. 27). Kundnani also argues that there was 'strong evidence' to suggest that Prevent-funded services had been used to gather intelligence on some of the Muslim communities (2009, p. 28).

The point here is that racist sentiments are being re-presented, distorted and used in ways to gain support for ever more intrusive and controlling measures. This occurs in such a way that problematic behaviour by the state is accepted and even fuelled by the public, making the victimisation of brown bodies two-fold. This is illustrated in the account of an American attorney who witnessed a 'raid' in the days following 9/11:

I was on my way home and found my block was closed off by SWAT teams and surrounded by police and emergency vehicles. A number of Arab and Middle Eastern families lived in one building. As I watched, men were led out and separated from their families. Women in headscarves carrying babies and holding children were lined up against the wall. The kids were crying. Helicopters hovered above flashing red, white and blue lights. A huge crowd of neighbours, representing in its make-up the diversity of the neighbourhood, watched and cheered, chanting "U-S-A! U-S-A!" (quoted in Mathur 2006, p. 35).

Here we can apply and develop Cohen's (1988) discussion of 'neighbourhood nationalism', where, rather than whiteness being used to reclaim space, a sub-nationalist identity based on identification with a non-brown (and non-Muslim) identity is being formed and used to mask the racist nature of this event. Indeed, what is interesting about this account is the way in which the diversity of the crowd seems to dilute significance of race. However, the nationalist symbols of the event, i.e. red, white and blue flashing helicopter lights (which remind us of the colours of the American Flag), and the 'U-S-A' chants, still represent a particular ethnically specific and culturally racist notion of an American identity. The construction of the brown body as a Muslim deviant therefore works and is in fact reliant on the excusing in this event of any deviant status (i.e. racist) that may have been applied to the practices of an ethnically discriminatory state and the surrounding crowd, who not only legitimate (in their passive observation and cheering of) state behaviour, but also encourage (in their chants) more like it. The crowd and the state as a whole are able to shake off their deviant status, because in this scenario they hold the white or 'closer to white' ethnic power to do so. The event has a stench of xenophobia and Islamophobia. There is 'selective racial consciousness' at play (Foster 2009, p. 686), which allows the use of racism, without the appearance of racism.

Within these supposed post-race times, this being an era marked out as having progressed with race equality, there exists a system where on the one hand there appear to be legalistic measures for combating such discrimination and protecting the human rights (10) of an already excluded and discriminated population, and yet, on the other hand, there is the securitisation (11) of race relations 
that is articulated within the context of the 'war on terror' to produce a new mode of discrimination that is closely associated with intensified forms of control and new modes of profiling and constructing racial categorisations (Patel and Tyrer 2011). These new forms of racism, i.e. Kundnani's (2001) 'new popular racism', or Fekete (2001) and Sivanandan's (2006) 'xeno-racism', combines in varied ways different types of discriminations, for instance, anti-Muslim racism, Islamophobia and xenophobia, in order to produce a particular type of cultural discrimination that is context specific and popularised as acceptable within post-race times. This is because they are viewed as not being (biologically) racist in nature, but more about community conflict and national security. A by-product of this is that there is little sympathy for the racism experienced by brown bodies, especially in relation to their 'Muslimness'. Meer and Modood (2010) suggest a number of reasons for this, including prominence of the view that protections from racism are afforded to conventionally, involuntarily conceived, racial minorities and should not be extended to those (Muslims) who voluntarily choose their religious identity, especially if, as is often envisaged in Christian thought, that religion is viewed as an oppressive one which requires members to be disloyal or associated with terrorism (Meer and Modood 2010, p. 124). This perception leads to brown bodies no longer just being seen as insular problem communities, but more-so now being considered as posing a wider security concern for Western societies (Dwyer et al. 2008). Thus we have a 'new national security agenda based on counter-terrorism with a specific focus on Islamic fundamentalism' (Brown 2008, p. 472).

\section{Excusing White Deviance}

What is a clearly racialised context also involves re-assigning labels of problem, racist and deviant, away from white bodies and placing them onto brown bodies. White bodies are able to do this because of the centrality of whiteness, and in particular its normative, moral and superior status - a privileged position emerging from centuries of practices in which whiteness has remained unchecked. This enables subjects of whiteness to (re)invent and change definitions of the racial / ethnic 'other' depending on the social, economic and political motivations of the given time. Because of the dominance of euro-centric thinking and practices, whiteness is self-perpetuated in Western society. This allows it to become a non-raced category. It has 'come to be represented as humanness, normality and universality' (Garner 2007, p. 34). Furthermore, it is imagined within the 'myth of the colonial saviour' who 'provides charismatic leadership for the oppressed Other..... whiteness as benevolent and selfless, and the people of colour encountered as in need of uplift and direction' (Garner 2007, p. 50). Whiteness is therefore the 'framing position' against which 'other' difference is measured 'whites are not of a certain race, they are just the human race' meaning that all else is deviant and requires qualification (Dyer 1997, p. 3). This standpoint has been used to view the symbolic and physical violence on black and minority ethnic others as being perceived by the white-self as granted and necessary. It also serves to prevent whiteness from being seen as a source of terror and supremacy in itself, as bell hooks (1992) notes: 'I think that one fantasy of whiteness is that the threatening other is always a terrorist. This projection enables many white people to imagine there is no representation of whiteness as terror, as terrorizing' (p. 174).

The power that the centrality of whiteness brings means that its subjects are more readily able to remove deviant labels from themselves. This is done by moving away from a deviant space, towards a more favourable one. In recent post-race times this has been achieved by moving towards a space in which they re-define themselves as the minority (12) group, who may further be subjected to victimisation. They carry out this 'stigma transformation' through successful 'frame transformation', that is, moving away from a 'deviant cultural space' to one in which they claim minority status. Thus they achieve 'normality' without changing actual behaviour (Berbrier 2002, pp. 554-557). This means that they (hold the power to still be able to) redefine the boundaries of normality according to their own needs - although not of central whiteness, they are nevertheless close enough to the centre, or at least much closer to it than their brown counterparts. In referring to the case of white supremacist groups in the USA, Berbrier (2002) highlights how they 'present themselves as having been labelled, 
stigmatised, or otherwise assigned status in a deviant cultural space, and to counter this they claim nondeviance' (p. 557). They 'manage' their deviant status or stigma (Goffman 1963) and perform 'stigma transformation' (Pfuhl and Hentry 1993, cited in Berbrier 2002, p. 557). They are able to do this because they still hold a position of power that allows them to use moral entrepreneurship to change the very meaning of the stigmatising label (Berbrier 2002, p. 557). They situate themselves in a position that marks them out as a minority group and gain empathy by arguing that they are responding in similar ways to how other minority groups have. In the case of white supremacist groups this has often included making reference to the beliefs, i.e. claims to empowerment and advancement of culture, that have been expressed by Black African American activists and minority groups, such as the Black Panthers, Malcolm X, and so on.

White bodies are more readily (although not always successfully) able to therefore de-stigmatise themselves and their cause. This reinforces the normality of their racist ideology. They place emphasis on positive approaches to a national identity - which goes hand in hand with a pro-white ideology, and cultural pride, rather than on an anti-black view and motivations of hate (Berbrier 2002). This is achieved through impression management, i.e. disassociation from its own past or other groups considered racist; illustrating an inclusive membership, sometimes even highlighting 'tokenistic' black minority ethnic members; denouncing violence; selective use of language (at least in the 'front of stage' setting (Foster 2009; Becker 1963; Goffman 1963)); and a reframing of meanings, so 'racism' becomes something that is normal, and about pride in heritage and culture (Berbrier 2002) or is something that is delivered in the form of 'race talk' that defends the 'white racial frame' (Foster 2009, p. 685). It can be argued that such de-stigmatisation via impression management is currently being undertaken by the English Defence League, which, in advocating a very selective view of English nationalism, has actively chosen to publicly distance itself from 'old-school' biological racism, such as that based on skin pigmentation, as used by its predecessors, i.e. the National Front. Recall for instance the English Defence League's burning of a swastika flag (which was often used by the National Front) in a Luton warehouse, which was screened on the BBC's Newsnight programme in October 2009. Although appearing to abandon older biological forms of racism, it can be argued that the English Defence League's Islamophobic sentiments remain historically linked to the biological racial hierarchy of European-Christian practices and the 'Orientalist' ideas of 'West' (Meer and Modood 2010; Said 1978). Clearly harbouring Islamophobic sentiments (see the Mission Statement, detailed on its website), the English Defence League has been 'selective' in its discrimination (Copsey 2010), by carefully harnessing existing culturally racist views within mainstream society, and then going on to re-frame them within discussions about 'human rights', 'English culture' and the threat of 'Sharia law......being adapted and enforced in England' (English Defence League 2012). No direct mention of whiteness is made, yet it delivers an ideal loaded with racial bias, whilst at the same time working within the boundaries of race equality. In creating further panic about Muslim populations, the English Defence League plays on white grievances and feelings of victimisation, presenting the 'Islamic other' as a scapegoat for society's ills (Treadwell and Garland 2011).

It is argued that this careful re-presentation of English Defence League values and beliefs allows for any direct accusations of xenophobia, racism and fascism to be refuted, to such a degree that some may now refer to the English Defence League as a social populist mass movement (Allen 2011; Sheffield 2011). Thus, the English Defence League has been largely successful in de-stigmatising itself. This is evidenced not least in its rapid and 'unprecedented' growth since 2009 (Allen 2011). Although relatively little is known about its members, the English Defence League today boasts both active support, as illustrated by its ability to mobilise up to 3,000 supporters to protest in English towns and cities, and passive support, or what it calls its estimated 30,000 'armchair warriors' (Allen 2011, p. 285). Of particular interest though are the multilayered levels of support and membership of the English Defence League, including small numbers of Hindus, Sikhs and Jews, in other words those 'groups that have historically been discriminated against by the far right movement' - see Allen 
(2011, p. 279) for a greater discussion of English Defence League membership. What is clear is that regardless of some of the English Defence League's own problematic views, which echo the British National Party's anti-Muslim sentiments, i.e. evidenced in the latter's campaigns such as 'Islam out of Britain' and 'The Truth about Islam', and despite its links to violence - see for instance Treadwell and Garland (2011), the English Defence League has de-stigmatised itself by making reference to its cause as a minority rights issue and its claims that Englishness is being marginalised. This allows it to move away from the stigma associated with previous far-right groups and to gain 'respectability' and support from 'ordinary people' (Allen 2011, p. 284).

These are clear instances where white bodies have behaved problematically or criminally. However, there has been somewhat of a reluctance to assign deviant labels to the protagonists involved, although sometimes they are temporarily moved to the position of being slightly off-centre of whiteness - a position which this paper argues still holds some advantages of white privilege. Even when a deviant status has been initially assigned, the long-term result is a non-sticking of the status. It is argued that what has occurred here is the excusing of deviance. This draws on a racialised power imbalance born out of a deep rooted racism typically embedded in euro-centric Western societies, and where the use of diversion strategies under-play some deviant labels and over-play others. The result is that not only do any would be (or should be) deviant labels on white ethnic bodies not stick, but, if they do, they have greater possibility of shedding. This can occur through the potentially stigmatising deviant label being removed, as the deviant action is deemed understandable or as a justified response to their victimhood, by which we read: 'white victimhood' (13). Use of this victimhood rationale is clearly evident in the shooting of Menezes, where the Metropolitan Police's and officers' actions were defended as a rational and acceptable way of dealing with suspected suicide bombers, even though Menezes was innocent of any criminal activity (Vaughan-Williams 2007; O'Driscoll 2008). This was illustrated in the reluctance to view officers as having acted wrongly, or in deviant/criminal ways. Furthermore, the then Prime Minister, Tony Blair, even called for us to give our support to the officers involved (O'Driscoll 2008), which further valorized the killing (Vaughan-Williams 2007, p. 178). In fact, wider calls were made for us to excuse them of their 'mistake' (Sir lan Blair, quoted in The Daily Telegraph 31st January 2006). The officers involved were presented as having made the right choice, given the stressful conditions that they were working in, and it was suggested that for this they should be excused of their 'error' and credited for their bravery. Any status of deviance had in this case been de-constructed and replaced with heroic ones instead. This was made possible because of the reluctance to admit 'white guilt', which as Pugliese (2008) notes was evident in how the Menezes surveillance was framed within a 'regime of visuality' which fused 'fantasy and fiction.....into factual reality' (Pugliese 2006, p. 3), evidenced in the presentation of a light-skinned Brazilian into a darkerskinned Asian (Vaughan-Williams 2007). Even after his death, the Metropolitan Police Force released images that had been doctored to show Menezes as having a much darker skin tone (similar to that of the original target of the operation, Hussein Osman) than was really the case (The Times 17th October 2007). This was a practice used in an attempt to 'explain' their shooting 'mistake'. In comparison, the very real status of innocence for Menezes had been replaced with a deviant one instead, even when that status proved false. Using cases from the USA, Garner (2007, p. 20) notes how the white power to define even allows the crimes of white perpetrators to be blamed on fictitious black and minority ethnic groups.

Also in these rungs, there are those sub-divisions of white deviance which are seen as undesirable and as a result hold a less amount of power than their central-white or off-centre-white counterparts (Hartigan 1997; Yulkins 2003). Haylett (2001) refers to them as 'abject whites' who are 'seen to embody an unsettling mix of whiteness, "working classness", and poverty' (Haylett 2001, cited in Rhodes 2011, p. 107). Such groups, who are often referred to as: 'white trash' (Hartigan 1997, p. 53), are seen as being of a lower class status, part of which involves engaging in problematic behaviour, i.e. single parenthood (usually motherhood); alcoholism or drug addiction; welfare-dependency; etc. They are 
accused of being prone to laziness and criminal behaviour, whose presence goes on to threaten (white) social order. Thus, white labels are also negotiated on an 'intra-racial' basis (Hartigan 2005, cited in Rhodes 2011, p. 107), meaning that belonging to whiteness does not always bring with it a high status of privilege and an automatic ability to shed deviant labels. For example, it is important to note that in the off-centre spaces of whiteness, there is another off-centre rung, more away from the centre, whose behaviour is clearly racially motivated and universally abhorrent. Consider for instance the cases of David Copeland, the London nail-bomber in April 1999, and, more recently, Anders Behring Breivik, who carried out murders in Oslo, Norway in July 2011. However, it is argued that often in such cases, the racist motives of these white criminals are represented in a narrative that detaches the significance of 'white terror' and racial oppression (hooks 1992). Instead these bodies are presented as lone, psychologically disturbed, individuals, unlike the rest of society, who harbour problematic views which are uncommon.

Whiteness does though bring with it an easier ability to shed deviant and / or racist labels, when compared to the opportunities afforded to their brown counterparts. Within the terror-panic context, the case of white converts to Islam has often been presented as an example of how particular categories of whiteness within certain contexts struggle to obtain (and may not always successfully achieve) a fully 'excused' status. Accused of being a 'white Paki', they are seen as traitors to the white race (Franks 2000). White converts, especially those who mark out their faith by wearing visible signs of ethnic difference, which for men includes growing a beard or wearing sunnah clothes, or for women wearing the hijab, jilbab or niqab for instance, are open to similar types of discrimination to that faced by their brown bodied counterparts. However, it is argued that, although considered to be 'race-traitors' and undoubtedly subjected to a gaze of hate, their experience of race-hate differs to that of the brown body. It is argued that white converts are considered by other white bodies as oppressed (especially female ones) and confused. They are at the same time viewed with pity, for having fallen under the spell of the brown body, and for ultimately having denied themselves their own right to superiority (Franks 2000). In this sense, they are a victim; a victim that needs to be guided through these dark and confusing times. For the white convert then, there may be a way back - an absolution of their 'dark' sin. Despite spiritually (i.e. through religious customs) and physically (i.e. through dress) having crossed the boundaries of whiteness, they are and always will be given that they possess natural (biological) whiteness, afforded the opportunity of being able to return to their whiteness. This is a constant in their lives, which means that although as white converts to Islam they become racially 'otherized' and subsequently experience a form of what Franks calls 'racism by proxy' (2000, p. 923), they nevertheless hold the ability to excuse their sin or to tell white lies by masking their conversion - an opportunity ill afforded to brown bodies, whether they be of the Muslim faith and choose to visibly symbolise this, or otherwise - see Jensen (2008) for an interesting discussion on white Danish converts to Islam.

\section{Conclusion}

Using the case of terror-panics, this paper has considered perceptions of deviance within post-race times. It has been argued that constructions of deviance draw on a racist discourse that is framed within anti-Muslim and white centrality rhetoric. This rhetoric is abundant in daily speech and is legitimated by local and global politics that are pre-occupied with notions of failed multiculturalism and the need to reinforce membership to a particular version of national identity, via the protection of borders, community cohesion and increased immigration controls. In heightening some black and minority ethnic identities over others, subjects are made visible, or as Khoury (2009) argues, they are presented as 'hyper-visible'. They are seen as 'outsiders', 'dangerous others', 'hostile enemies', which are further viewed with suspicion and as objects in need of state intervention. Their visibility, or 'stigma' (Goffman 1963), is not only marked out by biological features such as skin pigmentation, but is also considered to be voluntarily developed by cultural factors. In this sense black and minority ethnic groups are often blamed for being co-conspirators of their stigma. Meer and Modood (2010) 
note for instance that attempts to highlight anti-Muslim racism and Islamophobia have often led to criticism of Muslims themselves. At the same time, racialisation processes within the terror-panic context allow for the deviant behaviour of white ethnic bodies to have greater power and access to de-stigmatisation opportunities. This is because of the normative and central status of whiteness, and the new racisms of a post-race era. This involves presenting whiteness as an ethnic category that is normal, moralistic and just. Their deviant label is thus shed, and they are presented as the guardians of whiteness and civilisation. Given its moral centrality, whiteness is passed over for questioning or not sufficiently held to account, even in the face of wrong-doing. Their ethnicity certainly doesn't act as a pre-fix to their deviance in the same way as it does for black and minority ethnic bodies. The result is differential treatment and outcomes in matters relating to crime, justice and victimisation.

This paper has argued that because brown bodies, as ethnically marked suspect populations, are in a relatively powerless position, along with the popularity of Islamophobia and new forms of racism themselves framed within white superiority rhetoric, the ability of brown bodied subjects to remove the allocation of a deviant status, and its pro-longed stigma, is somewhat limited. It is true that some challenges may be successful, for instance illustrated in the response to the increased use of CCTV cameras in the Washwood Heath and Sparkbrook wards of Birmingham (UK), areas known to be predominantly populated by Muslims (14) (BBC News 6th August 2010). However, to do so successfully depends on the power held by control agents and the socio-political climate within which the 'battle' unfolds (Pfohl 2002). And, although to challenge the assigning of a deviant label is especially important for those who have been labelled a deviant, but who in fact have not broken a rule (Becker 1963), it is argued that as a relatively powerless group in society, deviant labels on brown bodies tend to stick. For example, consider the cases of those post 9/11 arrestees and detainees, who years after being cleared of all links to terrorism were unable to resume their normal lives, sometimes even when they left the USA and returned home to Turkey, Egypt or India, because the presumption of guilt followed them (Mathur 2006, p. 32). The situation however differs for white bodies, which are able to more easily shed stigma and have their deviance excused. They have this power, and use it because of the privileged position that they as white bodies hold in contemporary Western societies.

\section{Notes}

(1) Code A of the Police and Criminal Evidence Act (1984) states it is unlawful for a police officer to discriminate on the grounds of race or ethnicity. However, an update of the Act following the Terrorism Act (2000) does allow officers to take into account the individual's ethnicity in their selection of persons to search: '..... [t] here may be circumstances, however, where it is appropriate for officers to take account of a person's ethnic origin in selecting persons to be stopped in response to a specific terrorist threat, for example, some international terrorist groups are associated with particular ethnic identities' (Police and Criminal Evidence Act 1984, code A, para.2.25).

(2) Sections 44 and 45 of the Terrorism Act (2000) enabled the police and the Home Secretary to define any area in the country and a time period wherein they could stop and search any vehicle or person, with section 45 allowing this power to be exercised 'for the purpose of searching for articles of a kind which could be used in connection with terrorism, and..... may be exercised whether or not the constable has grounds for suspecting the presence of articles of that kind' (Terrorism Act 2000, section 44, 1-a/b). In January 2010 these stop and search powers were ruled illegal by the European Court of Human Rights, and the time of writing this paper the British government were reviewing its use and powers.

(3) Previously, reference to ethnic grouping often talked about all those who were non-white. This was based on the assumption that whiteness was the ethnic norm, and thus unmarked, rendered invisible and unbefitting examination (Burdsey 2011), and certainly something that was viewed as unobtainable or unmatchable - although Ignatiev (1995) highlights some ability to do this within certain boundaries. Discussion of whiteness as an ethnic category in itself was therefore almost absent from public recognition, and limited in academic discussions, even anthropological ones, and certainly criminological and sociological ones. This is not surprising given the racist roots of these disciplines (Patel and Tyrer 2011). 
(4) The English Defence League is a far-right movement which uses, amongst other strategies, street protest, as a way of demonstrating its opposition to what it considers to be a spread of Islamism, Sharia Law and Islamic extremism in England. It is a group that boasts of non-white membership and thus claims not to be a racist group. However, it has been alleged by critics that anti-Muslim sentiment and sympathies with the British National Party, as well as connections with other far-right groups in the USA and Europe, are key to the group's ideology.

(5) Having been 'mistaken' (Sir lan Blair, quoted in The Daily Telegraph 31st January 2006) for a suspected terrorist, 27 year old Brazilian Jean Charles de Menezes was shot seven times and killed by officers of the London Metropolitan Police at Stockwell Tube Station on 22nd July 2005 (Justice4Jean 17th July 2011).

(6) This paper does not dispute the fact that that nineteen of the 9/11 hijackers were of Arab origin (Spencer 2008), and themselves had claimed to have committed these attacks in the name of Islam, as others have in terror attempts in the years that followed.

(7) The Macpherson Report (1999) followed the 1993 racist murder of Stephen Lawrence, a black African Caribbean youth in London. The report highlighted failures of the Metropolitan Police Service, highlighting problems of institutional racism in the investigation, and made a number of recommendations for criminal justice institutions.

(8) Consider for instance the $£ 12.5$ million government funded Channel Project, set up in April 2007 under the British government's wider Prevent Counter Terrorism programme, which at time of writing this paper was under review. The Channel Project asked school teachers to seek out and report pupils which they suspected may be at risk of radicalisation and participating in violent behaviour.

(9) This is the screening of personal data in order to track individuals presenting suspects' features. The criteria established in this case included being male, Muslim, and from one of 26 listed countries with a predominantly Muslim population (De Schutter and Ringelheim 2008, p. 359).

(10) This is laid out in various UK based and European wide anti-discrimination legislation, i.e. Articles 2 and 26 of the International Covenant on Civil and Political Rights (1976); Protocol 12 to the European Convention on Human Rights (1953); the International Convention on the Elimination of All Forms of Racial Discrimination (1969), and so on, all of which prohibit racial, ethnic or religious based discrimination and the right to security and protection of fundamental human rights.

(11) Malmvig (2005, p. 335) highlights how 'securitization' does 'not necessarily mean that the word 'security' is used, but that an imminent danger is constructed, that a threatening future is invoked, which demands urgent attention. Securitization is about dramatizing and bringing urgency to a certain matter, because it threatens the world as we know it'.

(12) Here I take from Wirth's (1945) definition of a 'minority' group, as a label used to refer to 'a group of people who, because of their physical or cultural characteristics, are singled out.....for differential and unequal treatment, and who therefore regard themselves as objects of collective discrimination' (p. 347).

(13) The notion of 'white victimhood' refers to a white perception that they are a socially, economically and politically marginalized group. In recent years, this notion has gained increased momentum, utilized not least by far right groups, who have argued that 'black advantage' has led to 'white victimisation'. It has thus been used to justify new forms of racism and discriminatory behaviour. At the time of writing this paper, notions of 'white victimhood' were being presented as way of re-framing the July 2011 terrorist actions of Anders Behring Breivik in Norway, this was after initial media reports ran with a story that blamed a 'homegrown alQaeda convert' and a 'homegrown Islamic convert' (Sun Newspaper 23rd July 2011).

(14) Upon discovering that the cameras had been paid for by a Government grant from the Terrorism and Allied Matters Fund, after initially being told that the cameras would be there to reduce vehicle crime, drugs offences and anti-social behaviour in these areas (Guardian 4th June 2010), some residents responded by 
challenging the presented reasons for having so many (i.e. a total of 216) cameras erected in these areas.

\section{References}

Ahmad, F. (2006). British Muslim Perceptions and Opinions on News Coverage of September 11. Journal of Ethnic and Migration Studies. 32(6), pp. 961-982.

Alexander, C. (2005). Embodying Violence: 'Riots', Dis/order and the Private Lives of the Asian Gang. In: Alexander, C. and Knowles, C. eds. (2005). Making Race Matter: Bodies, Space and Identity, pp. 199-217. Basingstoke: Palgrave.

Allen, C. (2010). Contemporary Islamophobia Before 9/11: A Brief History. Arches Quarterly. 4(7), pp. 14-22. Allen, C. (2011). Opposing Islamification or Promoting Islamophobia? Understanding the English Defence League. Patterns of Prejudice. 45(4), pp. 279-294.

Bahdi, R. (2003). No Exit: Racial Profiling and Canada's War Against Terrorism. Osgoode Hall Law Journal. 41(2-3), pp. 293-318.

Ball, K. and Webster, F. eds. (2003). The Intensification of Surveillance: Crime, Terrorism and Warfare in the Information Era. UK: Pluto Press.

BBC News (2005). I Saw Tube Man Shot - Eyewitness. [Online]. (Retrieved July 2005) (URL: http://news.bbc. co.uk/1/hi/uk/4706913.stm).

BBC News (2010). Birmingham CCTV System Leaves Police Trust in Tatters. [Online]. (Retrieved August 2010) (URL: http://www.bbc.co.uk/news/uk-10888985).

Becker, H.S. (1963). Outsiders. New York: Free Press.

Berbrier, M. (2002). Making Minorities: Cultural Space, Stigma Transformation Frames, and the Categorical Status Claims of Deaf, Gay, and White Supremacist Activists in Late Twentieth Century America. Sociological Forum. 17(4), pp. 553-591.

Bhattacharyya, G. (2008). Dangerous Brown Men: Exploiting Sex, Violence and Feminism in the War on Terror. London: Zed Books.

Brown, K. (2008). The Promise and Perils of Women's Participation in UK Mosques: The Impact of Securitisation Agendas on Identity, Gender and Community. British Journal of Politics and International Relations. 10, pp. 472-491.

Burdsey, D. (2011). 'Strangers on the Shore': Racialized Representation, Identity and In/visibilities of Whiteness at the English Seaside. Cultural Sociology. June 2011, pp. 1-16.

Burman, J. (2010). Suspects in the City: Browning the 'Not-Quite' Canadian Citizen. Cultural Studies. 24(2), pp. 200-213.

Cohen, S. (1972). Folk Devils and Moral Panics: The Creation of the Mods and Rockers. London: MacGibbon and Kee.

Cohen, P. (1988). The Perversions of Inheritance: Studies in the Making of Multi-racist Britain. In: Cohen, P. and Bains, H. eds. (2006). Multi-racist Britain, pp. 9-16. Basingstoke: Macmillan.

Copsey, N. (2010). The English Defence League: Challenging Our Country and Our Values of Social Inclusion, Fairness and Equality. UK, Faith Matters.

Covington, J. (1995). Racial Classification in Criminology: The Reproduction of Racialized Crime. Sociological Forum. 10(4), pp. 547-568.

De Schutter, O. and Ringelheim, J. (2008). Ethnic Profiling: A Rising Challenge for European Human Rights Law. Modern Law Review. 78(3), pp. 358-384.

Dwyer, C., Shah, B., and, Sanghera, G. (2008). From Cricket Lover to Terror Suspect - Challenging Representations of Young British Muslim Men. Gender, Place and Culture. A Journal of Feminist Geography. 15(2), pp. 117-136.

Dyer, R. (1997). White. London: Routledge.

English Defence League (2012). Mission Statement. [Online]. (Retrieved April 2012) (URL: http:// englishdefenceleague.org/about-us/mission-statement/).

Entman, R.M. (1990). Modern Racism and the Images of Blacks in Local Television News. Critical Studies in Mass Communication News. 7(4), pp. 332-345.

European Convention on Human Rights. (1953). London: HMSO.

Fekete, L. (2001). The Emergence of Xeno-racism. Race and Class. 43(2), pp. $23-40$.

Foster, J.D. (2009). Defending Whiteness Indirectly: A Synthetic Approach to Race Discourse Analysis. Discourse and Society. 20(6), pp. 685-703.

Franks, M. (2000). Crossing the Borders of Whiteness? White Muslim Women Who Wear the Hijab in Britain 
Today. Ethnic and Racial Studies. 23(5), pp. 917-929.

Garner, S. (2007). Whiteness: An Introduction. London: Routledge.

Gilroy, P. (2005). Multiculture, Double Consciousness and The 'War on Terror'. Patterns of Prejudice. 39(4), pp.431-443.

Gilroy, P. (2006). Multiculture in Times of War: An Inaugural Lecture Given at the London School of

Economics. Critical Quarterly. 28(4), pp. 27-45.

Goffman, E. (1963). Stigma: Notes on the Management of a Spoilt Identity. London: Penguin.

Guardian (2010). Anti-terror Stop and Search Powers to be Scrapped. [Online]. (Retrieved July 2010) (URL: http://www.guardian.co.uk/law/2010/jul/o8/anti-terror-stop-and-search-scrapped).

Guardian (2010). Surveillance Cameras in Birmingham Track Muslims' Every Move. [Online]. (Retrieved June 2010) (URL: http://www.guardian.co.uk/uk/2010/jun/o4/surveillance-cameras-birmingham-muslims).

Haggerty, K.D. and Gazso, A. (2005). Seeing Beyond the Ruins: Surveillance as a Response to Terrorist

Threats. Canadian Journal of Sociology. 30(2), pp. 169-188.

Hall, S., Critcher, C., Jefferson, T., Clarke, J., and Roberts, B. (1978). Policing the Crisis: Mugging, the State, and Law and Order. London: Macmillan.

Harewood, S. (2010). Tings Brown: Nationalists, Regionalists and Tourists Making Claims in the State. Cultural Studies. 24(2), pp. 214-233.

Hartigan, J. (1997). Name Calling: Objectifying 'Poor Whites' and 'White Trash' in Detroit. In: Wray, M. and Newitz, A. eds. (1997). White Trash: Race and Class in America, pp41-56. New York: Routledge.

hooks, b. (1992). Black Looks: Race and Representation. Boston: South End Press.

Ignatiev, N. (1995). How the Irish Became White. London: Routledge.

Independent Police Complaints Commission (2007). Stockwell One: Investigation into the Shooting of Jean

Charles de Menezes at Stockwell Underground Station on 22 July 2005. London: IPCC.

International Covenant on Civil and Political Rights. (1976). London: HMSO.

International Convention on the Elimination of All Forms of Racial Discrimination. (1969). London: HMSO.

Jackson, R. (2006). Religion, Politics and Terrorism: A Critical Analysis of Narratives of 'Islamic Terrorism'.

Centre for International Politics Working Paper Series No. 21. [Online]. (Retrieved April 2011) (URL: http:// www.socialsciences.manchester.ac.uk/disciplines/politics/about/themes/cip/publicatiogs/documents/ Jackson_ooo.pdf).

Jensen, T.G. (2008). To Be 'Danish', Becoming 'Muslim': Contestations of National Identity? Journal of Ethnic and Migration Studies. 34(3), pp. 389-409.

Justice4Jean (2011). The Jean Charles De Menezes Family Campaign. [Online]. (Retrieved July 2011) (URL: http://www.justice4jean.org/).

Khiabany, G. and Williamson, M. (2008). Veiled Bodies, Naked Racism: Culture, Politics and Race in The Sun. Race and Class. 50(2), pp.69-88.

Khoury, L.J. (2009). Racial Profiling As Dressage: A Social Control Regime! African Identities. 7(1), pp. 55-70. Kundnani, A. (2001). In A Foreign Land: The New Popular Racism. Race and Class. 43(2), pp. 41-60.

Kundnani, A. (2007). The End of Tolerance. London: Pluto Press.

Kundnani, A. (2009). Spooked: How Not to Prevent Violent Extremism. London: Institute of Race Relations. Lugo-Lugo, C.R. and Bloodsworth-Lugo, M.K. (2010). $465^{\circ}$ From September 11; Citizenship, Immigration, Same-sex Marriage and the Browning of Terror. Cultural Studies. 24(2), pp. 234-255.

Lyon, D. (2006). Airport Screening, Surveillance, and Social Sorting: Canadian Responses to 9/11 Context. Canadian Journal of Criminology and Criminal Justice. 48(3), pp. 397-411.

Lyon, D. (2007). Resisting Surveillance. In: Hier, S.P. and Greenberg, J. eds. (2007). The Surveillance Studies Reader, pp. 368-377. Maidenhead: Open University Press.

Macpherson of Cluny, Sir W. (1999). The Stephen Lawrence Inquiry. Cm. 4262-1. London: Home Office.

Malik, S. (2002). Representing Black Britain: Black and Asian Images on Television. London: Sage.

Malmvig, H. (2005). Security Through Intercultural Dialogue? Implications of the Securitization of Euro-

Mediterranean Dialogue Between Cultures. Mediterranean Politics. 10(3), pp. 349-364.

Manchester Evening News. (2008). Top Cop's Terrorism Warning. [Online]. (Retrieved June 2008) (URL: http:// menmedia.co.uk/manchestereveningnews/news/s/1044398_top_cops_terrorism_warning).

Mathur, S. (2006). Surviving the Dragnet: 'Special Interest' Detainees in the US after $9 / 11$. Race and Class. 47(3), pp. 31-46.

McGhee, D. (2005). Intolerant Britain? Hate, Citizenship and Difference. Berkshire: Open University Press.

Meer, N. and Modood, T. (2010). Analysing the Growing Scepticism Towards the idea of Islamophobia. Arches Quarterly. 4(7), pp. 116-126. 
Moore, K., Mason, P., and Lewis, J. (2008). Images of Islam in the UK: The Representation of British Muslims in the National Print News Media 2000-2008. Cardiff: Cardiff School of Journalism, Media and Cultural Studies. Moeckli, D. (2007). Stop and Search Under the Terrorism Act 2000: A Comment on R (Gillan) v Commissioner of Police for the Metropolis. Modern Law Review. 70(4), pp. 659-670.

Murray, N. (2010). Profiling in the Age of Total Information Awareness. Race and Class. 52(3), pp. 3-24. O'Driscoll, C. (2008). Fear and Trust: The Shooting of Jean Charles de Menezes and the War on Terror. Millenium - Journal of International Studies. 36(2), pp. 339-360.

Patel, T.G. and Tyrer, D. (2011). Race, Crime and Resistance. London: Sage.

Perry, B. (2001). In the Name of Hate: Understanding Hate Crimes. New York: Routledge.

Pfohl, S. (2002). Images of Deviance and Social Control. In: Weitzer, R. ed. (2002). Deviance and Social Control, pp.5-8. New York: McGraw-Hill.

Police and Criminal Evidence Act. (1984). London: HMSO.

Poole, E. (2002). Reporting Islam: Media Representation of British Muslims. London: I.B.Touris and Company Limited.

Poole, E. and Richardson, J.E. (2006). Muslims in the News Media. London: I.B.Touris and Company Limited. Pugliese, J. (2006). Assymmetries of Terror: Visual Regimes of Racial Profiling and the Shooting of Jean Charles de Menezes in the Context of the War in Iraq. Borderlands E-Journal. 5(1). [Online]. (Retrieved July 2011) (URL: http://www.borderlands.net.au/vol5no1_2006/pugliese.htm).

Razack, S. (2008). Casting Out: The Eviction of Muslims from Western Law and Politics. Toronto: Toronto University Press.

Rhodes, J. (2011). 'It's Not Just Them, It's Whites as Well': Whiteness, Class and BNP Support. Sociology. 45(1), pp. 102-117.

Richardson, J.E. (2004). (Mis)Representing Islam: The Racism and Rhetoric of British Broadsheet Newspapers. Amsterdam: John Benjamins Publishing Company.

Saeed, A. (2007). Media, Racism and Islamophobia: the Representation of Islam and Muslims in the Media. Sociology Compass. 1(2), pp. 443-462.

Said, E. (1978). Orientalism. New York: Pantheon Books.

Semati, M. (2010). Islamophobia, Culture and Race in the Age of Empire. Cultural Studies. 24(2), pp. 256-275. Sheffield, J. (2011). 'Bye-Bye Fascists': A Critical Analysis of the English Defence League. Internet Journal of Criminology. [Online]. (Retrieved April 2012) (URL: http://www.internetjournalofcriminology.com/ Sheffield_A_Critical_Analysis_of_the_English_Defence_League_IJC_Aug_2011.pdf).

Sivanandan, A. (2006). Race, Terror and Civil Society. Race and Class. 47(1), pp. 1-8.

Sommers, S.R., Apfelbaum, E.P., Dukes, K.N., Toosi, N., and, Wang, E.J. (2006). Race and Media Coverage of Hurricane Katrina: Analysis, Implications, and Future Research Questions. Analyses of Social Issues and Public Policy. 6(1), pp. 1-17.

Spalek, B., El Awa, S., and, McDonald, L.Z. (2009). Police-Muslim Engagement and Partnerships for the Purposes of CounterTerrorism: An Examination. London: Arts and Humanities Research Council and Birmingham, University of Birmingham.

Spencer, A. (2008). Linking Immigrants and Terrorists: The Use of Immigration as an Anti-Terror Policy. The Online Journal of Peace and Conflict Resolution. 8(1), pp. 1-24. [Online]. (Retrieved April 2012) (URL: http:// www.trinstitute.org/ojpcr/8_1spencer.pdf).

Sun Newspaper (2011). Al-Qaeda Massacre: Norway's 9/11. Saturday 23rd July 2011.

Terrorism Act. (2000). London: HMSO.

The Daily Telegraph (2006). Met Chief Admits Serious Mistake Over De Menezes. 31st January 2006.

The Times (2007). De Menezes Picture 'Doctored' by Met Police. [Online]. (Retrieved October 2007) (URL: http://www.timesonline.co.uk/tol/news/uk/article2678733.ece).

Treadwell, J. and Garland, J. (2011). Masculinity, Marginalization and Violence: A Case Study of the English Defence League. British Journal of Criminology. 51, pp. 621-634.

Vaughan-Williams, N. (2007). The Shooting of Jean Charles de Menezes: New Border Politics? Alternatives: Global, Local, Political. 32, pp. 177-195.

Wirth, L. (1945). The Problem of Minority Groups. In: Linton, R. ed. (1945). The Science of Man (Woman) in the World Crisis, pp. 347-372. New York: Columbia University Press.

Worley, C. (2005). 'It's not about Race, it's about the Community': New Labour and Community Cohesion. Critical Social Policy. 25(4), pp. 483-496.

Young, J. (1971). The Drugtakers. London: MacGibbon and Kee.

Younge, G. (2003). It's Over, Over There. Index on Censorship. 32, pp: 112-118. 
Yukins, E. (2003). 'Feeble-Minded' White Women and the Spectre of Proliferating Perversity in American Eugenics Narratives. In: Cuddy, L.A. and Roche, C.M. eds. (2003). Evolution and Eugenics in American Literature and Culture: 1880-1940, pp164-186. Massachusetts: Rosemont Publishing. 